\title{
PERAN SISTEM PENGENDALIAN INTERNAL PEMBERIAN KREDIT DALAM MEMINIMALISASI NON PERFORMING LOAN PADA PT BANK MITRANIAGA, Tbk
}

\author{
Retno Martanti E.L. ${ }^{1)}$ dan Masruroh $^{2)}$
}

\begin{abstract}
ABSTRAK
Pemberian kredit merupakan salah satu bisnis utama bank yang menghasilkan pendapatan bagi perusahaan, namun di sisi lain pemberian kredit memiliki risiko. Risiko tersebut adalah munculnya kredit bermasalah (Non Performing Loan) atau yang sering disebut dengan kredit macet. Penelitian ini ditunjukan untuk menjelaskan peran sistem pengendalian internal pemberian kredit dalam meminimalisasi Non Performing Loan pada PT Bank Mitraniaga, Tbk. Metode analisis yang digunakan adalah deskriptif kualitatif dan kuantitatif statistik. Hasil penelitian ini menunjukan bahwa hasil analisis korelasi diperoleh nilai korelasi sebesar - 0,844 dan signifikan 0,000, hal ini dapat diartikan bahwa sistem pengendalian internal pemberian kredit berpengaruh negatif dan signifikan terhadap Non Performing Loan pada derajat keyakinan 5\%. Nilai Koefisisen Determinasi (Kd) sebesar 71,3\% dapat diartikan bahwa peran sistem pengendalian internal pemberian kredit terhadap Non Performing Loan sebesar 71,3\%, sedangkan sisanya sebesar $28,7 \%$ dijelaskan atau dipengaruhi oleh faktor lain yang tidak diteliti seperti faktor eksternal, faktor internal nasabah, dan faktor kegagalan bisnis.
\end{abstract}

Kata Kunci : Sistem Pengendalian Internal Pemberian Kredit dan Non Performing Loan.

\begin{abstract}
The one of the main business of banks is give a credit that generate revenue for the company, but on the other hand lending has risks. The risk is the emergence of NPL (Non Performing Loan) or often referred to as bad credit. The higher non-performing loans of a banking company will affect the health of banks. It required a system of internal control lending is effectively enforced in order to assist the company in order to minimize the Non-performing Loan. This study is to explain the role of the internal control system of credit in minimizing non-performing loans at PT Bank Mitraniaga, Tbk. by using primary data and secondary data. The analytical method that used is a qualitative and quantitative descriptive statistics. These results indicate that the correlation analysis values obtained significant correlation of 0.844 and 0.000, it could mean that the internal control system of crediting a significant negative effect on non-performing loans at 5\% degree of confidence. Koefisisen Value Determination (Kd) of $71.3 \%$ means that the role of the internal control system of credit to non-performing loans amount to $71.3 \%$, while the remaining amount $28.7 \%$ is explained or influenced by other factors that not examined such as external factors, customer internal factors, and factors of business failure.
\end{abstract}

Keywords: Internal Control Systems of Credit and Non Performing Loan.

\footnotetext{
${ }^{1}$ Dosen Tetap Fakultas Ekonomi Universitas Pakuan

${ }^{2}$ Mahasiswa Fakultas Ekonomi Universitas Pakuan
} 


\section{Pendahuluan}

Pemberian kredit merupakan salah satu bisnis utama bank yang menghasilkan pendapatan bagi perusahaan dan merupakan salah satu bagian terbesar dari aktiva yang dimiliki oleh perusahaan, namun disisi lain pemberian kredit memiliki risiko. Salah satu risiko dari pemberian kredit adalah munculnya kredit bermasalah (Non Performing Loan) atau yang sering disebut dengan kredit macet. Semakin tinggi Non Performing Loan suatu perusahaan perbankan akan mempengaruhi tingkat kesehatan bank. Oleh karena itu pemberian kredit harus dilaksanakan dengan cermat dan tepat, dan dilaksanakan oleh pegawai kredit yang mengerti dan memahami mengenai dasar-dasar perkreditan.

Non Performing Loan adalah suatu keadaan dimana nasabah sudah tidak sanggup membayar sebagian atau seluruh kewajibannya kepada bank seperti yang telah diperjanjikan. Non Performing Loans merupakan rasio keuangan yang berkaitan dengan risiko kredit. Risiko kredit adalah risiko terjadinya kerugian-kerugian akibat kegagalan pembayaran oleh peminjam (debitur), atau terjadinya kemerosotan kualitas kemampuan membayar hutang pihak debitur (Wawan H. Purwanto, 2011).

Pengendalian internal adalah pondasi dari tingkat keamanan dan kesehatan dari suatu bank. Pengendalian internal yang efektif dapat mengurangi kemungkinan kesalahan/ kekeliruan besar dan dapat membantu mendeteksi dini terhadap kemungkinankemungkinan risiko yang akan terjadi.

Penelitian ini merupakan replikasi atau pengulangan dari penelitianpenelitian terdahulu yang dilakukan oleh Olla Auryna (2009) dengan judul "Peran Pengendalian Internal Piutang dalam Meminimalkan Kerugian Pada PT.
Federal International Finance". Hasil penelitian tersebut menyimpulkan bahwa pengendalian internal piutang berperan dalam meminimalkan kerugian. Perbedaan dengan penelitian ini terletak pada lokasi penelitian, dalam penelitian ini penulis memilih PT. Bank Mitraniaga Tbk. Selain itu Penelitian ini merupakan ekspansi dari penelitian sebelumnya dengan menggunakan 2 variabel yaitu sistem pengendalian pemberian kredit dan Non Performing Loan.

Penelitian oleh Hery Sofyan (2008) dengan judul "Manfaat Sistem Pengendalian Piutang dalam Meminimalisasi Piutang Tak Tertagih Pada Perusahaan Leasing". Hasil penelitian tersebut menyimpulkan bahwa sistem pengendalian piutang sangat bermanfaat dalam meminimalisasi piutang tak tertagih. Perbedaan dengan penelitian ini terletak pada lokasi penelitian, dalam penelitian ini penulis memilih PT Bank Mitraniaga, Tbk.

Penelitian oleh Dewa Putu Gede Sumerta Yasa (2013) dengan judul "Pengaruh Komponen Pengendalian Internal Kredit pada Kredit Bermasalah BPR di Kabupaten Buleleng”. Hasil penelitian tersebut menyimpulkan bahwa komponen pengendalian internal kredit memiliki pengaruh yang negatif terhadap kredit bermasalah. Perbedaan dengan penelitian ini terletak pada lokasi penelitian dan tahun penelitian, dalam penelitian ini penulis memilih PT Bank Mitraniaga Tbk.

Bidang usaha PT Bank Mitraniaga, Tbk adalah bergerak di bidang perbankan sejak tahun 1989 sebagai perusahaan yang menyediakan produk dan layanan perbankan di Indonesia. Kegiatan usaha Bank Mitraniaga adalah menghimpun dana masyarakat yang kemudian disalurkan dalam bentuk pemberian kredit kepada perorangan maupun korporasi. Selain itu, Perseroan juga melaksanakan transaksi antar bank 
serta kegiatan-kegiatan investasi melalui penempatan pada instrument pasar uang atau pasar modal. Salah satu risiko usaha yang dialami oleh Bank Mitraniaga adalah risiko kredit yang merupakan bagian terbesar aktiva yang dimiliki perusahaan sebagai suatu bank adalah berupa kredit yang diberikan kepada nasabah. Risiko yang timbul apabila debitur tidak mampu dalam memenuhi kewajibannya baik berupa pokok pinjaman maupun bunganya.

\section{Landasan Teori}

\subsection{Pengertian Sistem Pengendalian Internal.}

Menurut Mulyadi (2002:180) definisi pengendalian intern sebagai berikut:

Pengendalian intern adalah suatu proses yang dijalankan oleh dewan komisaris, manajemen dan personil lainnya yang didesain untuk memberikan keyakinan memadai tentang keadaan laporan keuangan, kepatuhan terhadap peraturan yang berlaku, efektifitas dan efisiensi operasi.

Tujuan pokok dari sistem pengendalian intern dalam suatu perusahaan dapat dibedakan dalam empat tujuan pokok, yaitu :

1. Menjaga kekayaan organisasi

2. Mengecek ketelitian dan keandalan data akuntansi

3. Mendorong efisiensi

4. Mendorong dipatuhinya kebijakan manajemen.

Pengendalian intern merupakan suatu proses untuk mencapai tujuan tertentu. Pengedalian intern sendiri bukan merupakan suatu tujuan. Pengendalian intern merupakan suatu tindakan yang bersifat pervasif dan menjadikan bagian yang tidak terpisahkan. Pengendalian intern dijalankan dari setiap jenjang organisasi, yang mencakup dewan komisaris, manajemen, dan personil lainnya.
Menurut Boyton dkk (2003:373) pengertian pengedalian intern (internal control) sebagai berikut : Pengendalian intern adalah suatu proses yang dilaksanakan oleh dewan komisaris, manajemen, dan personel lainnya dalam bentuk suatu entitas yang dirancang untuk menyediakan keyakinan memadai berkenaan dengan pencapian tujuan dalam kategori berikut ini :

1. Keandalan laporan keuangan.

2. Kepatuhan terhadap hukum peraturan yang berlaku.

3. Efektivitas dan efesiensi operasi.

\subsection{Pengertian Non Performing Loan (NPL) \\ Menurut Dahlan Siamat (2004:} 174) menyatakan bahwa : "Salah satu faktor penyebab runtuhnya kondisi suatu bank yaitu adanya NPL yang melebihi batas kewajaran yang ditetapkan oleh BI. NPL timbul karena tidak kembalinya dana yang diberikan dalam bentuk kredit tepat pada waktunya".

Menurut Kamus Bank Indonesia, Non Performing loan (NPL) atau Non Performing Financing (NPF) adalah kredit bermasalah yang terdiri dari kredit yang berklasifikasi kurang lancar, diragukan dan macet. Termin NPL diperuntukkan bagi bank umum, sedangkan NPF untuk bank syariah.

Menurut Luh Gede Meydianawathi (2007 : 138) menyatakan bahwa, Non Performing Loans (NPLs) menunjukkan kemampuan kolektibilitas sebuah bank dalam mengumpulkan kembali kredit yang dikeluarkan oleh bank sampai lunas. Menurut Mudrajat Kuncoro (2002:462) Non Performing Loan (NPL) atau kredit macet adalah suatu keadaan dimana nasabah tidak sanggup membayar sebagian atau seluruh kewajibannya kepada bank seperti yang diperjanjikannya. 
Rasio NPL sesuai dengan SE No.6/23/DPNP tanggal 31 Mei 2004

dapat dihitung dengan rumus :

$$
N P L=\frac{\text { Kredit Bermasalah }}{\text { Total Kredit }} \times 100 \%
$$

\section{Metode Penelitian}

Objek penelitian pada penelitian ini adalah peranan sistem pengendalian internal pemberian kredit dalam meminimalisasi non performing loan. Unit analisis yang digunakan adalah Organization. Lokasi penelitian pada penelitian ini adalah Bank Mitraniaga. Bank Mitraniaga. Jenis data yang diteliti adalah data kualitatif dan kuantitatif statistik yang merupakan data primer dan sekunder. Teknik sampling yang digunakan adalah sampel jenuh dan alat analisis yang digunakan meliputi pengujian validitas, pengujian reliabilitas, analisis korelasi dan analisis koefisien determinasi.

\section{Hasil dan Pembahasan}

PT Bank Mitraniaga, Tbk mengelompokkan kredit kedalam beberapa jenis. Adapun jenis-jenis kredit yang diberikan antara lain:

1. Kredit Modal Kerja
a. Pinjaman Rekening Koran
b. Demand Loan

2. Kredit Investasi

3. Kredit Konsumsi
a. Kredit Pemilikan Mobil (KPM)
b. Kredit Pemilikan Rumah (KPR)

4. Kredit Tanpa Agunan (KTA)

5. Kredit Multiguna

Berdasarkan hasil penelitian, peran sistem pengendalian internal yang dilaksanakan oleh PT Bank Mitraniaga, Tbk dalam rangka meminimalkan Non Performing Loan antara lain :

1. Sistem pengendalian internal pemberian kredit telah melaksanakan fungsinya yang dilaksanakan oleh pihak-pihak yang terkait, terutama dalam ketaatan terhadap prosedur yang telah ditetapkan dalam melakukan setiap kegiatan khususnya dalam meminimalisasi Non Performing Loan Pada PT Bank Mitraniaga, Tbk. Perusahaan mempunyai kemampuan untuk selalu meningkatkan kinerja dari tenaga kerjanya, melalui perubahan peningkatan dari sistem pemberian kredit yang diterapkan dimana akan mempengaruhi pemberian kredit yang dikeluarkan oleh perusahaan. Adapun sistem pengendalian internal yang telah ditetapkan oleh PT Bank Mitraniaga, Tbk antara lain:

a. Penetapan struktur organisasi yang telah memisahkan tanggung jawab fungsional secara tegas.

b. Dilaksanakannya analisa 5C pada proses pemberian kredit dan pelaksanaan pengendalian intern, yaitu: Capacity, Capital, Collateral, Condition of Economic, Character.

c. Dilaksanakannya prosedur penilaian risiko kredit dengan baik dengan membentuk komite Management Risiko dan Satuan Kerja Management Risiko (SKMR) yang berfungsi untuk memberikan masukan dan melakukan pengawasan terhadap 
pengelolaan risiko perusahaan yang berguna untuk meminimalisasi risiko bank.

d. Perusahaan telah menetapkan tingkat kolektabilitas kredit untuk mengetahui kualitas kredit sehingga perusahaan dapat mengantisipasi risiko kredit secara dini.

e. Dilaksanakannya prosedur audit dengan baik pada proses pemberian kredit dan pemeriksaan atas kredit yang telah diberikan.

2. Non Performing Loan Ratio tertinggi pada PT Bank Mitraniaga, Tbk tahun 2010-2014 sebesar $1,77 \%$ pada tahun 2014 triwulan ke-2 dan rasio terendah sebesar $0,12 \%$ pada tahun 2012 triwulan ke-2 dan triwulan ke-3. Artinya bahwa Non Performing Loan Pada PT Bank Mitranaga, Tbk masih dalam kategori sehat, karena Non Performing Loan Pada PT Bank Mitraniaga, Tbk dari tahun 2010-2014 per triwulan 1 sampai triwulan 4 memiliki nilai rasio NPL dibawah 5\%. Hal ini sesuai dengan peraturan Bank Indonesia Nomor 6/10/PBI/2004 tanggal 12 April 2004 yang menetapkan tingkat kesehatan bank jika memiliki nilai NPL dibawah 5\% maka bank tersebut dalam kategori sehat.

3. Berdasarkan hasil penelitian, penulis melihat bahwa sistem pengendalian internal pemberian kredit pada PT Bank Mitraniaga, Tbk dapat membantu perusahaan dalam meminimalisasi non performing loan. Hal ini dapat terlihat dari nilai rasio non performing loan yang ada pada kategori sehat dari tahun 2010 sampai tahun 2014, hal ini karena adanya prosedur pemberian kredit yang dilaksanakan dengan efektif, penilaian risiko kredit yang dilaksanakan dengan efektif, penetapan tingkat kolektabilitas yang dapat membantu perusahaan mendeteksi secara dini risiko kredit yang akan terjadi, serta adanya penetapan dan penyelenggaraan pengendalian internal yang layak.

Berikut ini merupakan analisis statistik yang dilaksanakan oleh peneliti mengenai peran sistem pengendalian internal pemberian kredit dalam meminimalisasi Non Performing Loan. Analisis ini berdasarkan hasil kuesioner yang dibagikan kepada 20 orang responden dengan 30 butir pertanyaan dan Rasio Non Performing Loan pada PT Bank Mitraniaga, Tbk tahun 20102014 triwulan 1 sampai triwulan 4 .

1. Uji Validitas

Berdasarkan kriteria yang telah ditetapkan pada bab sebelumnya, bahwa bila korelasi tiap faktor tersebut positif dan besarnya $0,3 \mathrm{ke}$ atas maka instrumen tersebut dikatakan valid, apabila besarnya kurang dari 0,3 maka dalam instrument tersebut dinyatakan tidak valid. Adapun hasil perhitungan korelasi untuk ke-30 pernyataan tersebut dari analisis korelasi product moment terlampir di Lampiran 1.

2. Uji Reliabilitas

Dari item-item yang dinyatakan valid dalam analisis validitas instrument penelitian, maka untuk mengukur tingkat keandalam instrument tersebut peneliti melakukan uji realibilitas 
instrument penelitian. Untuk memudahkan pengujian reabilitas instrument tersebut, data diolah menggunakan program SPSS versi 19. Berdasarkan hasil analisis diatas di dapat nilai Alpha sebesar 0,964. sedangkan nilai $r$ kritis adalah 0,6. Hal ini menunjukan bahwa nilai Alpha lebih besar dari nilai $r$ kritis $(0,964>0,6)$. Artinya bahwa dari 30 pertanyaan mengenai sistem pengendalian internal pemberian kredit memiliki tingkat reabilitas sebesar 0,964, maka dengan demikian dapat diambil kesimpulan bahwa pernyataan pada variabel $\mathrm{x}$ adalah reliable.

2. Analisis korelasi product moment Analisis korelasi digunakan untuk mengetahui keeratan hubungan antara dua variabel dan untuk mengetahui arah hubungan yang terjadi. Untuk menganalisis korelasi pada variabel sistem pengendalian internal pemberian kredit peneliti menggunakan nilai total score dari setiap responden yang diurutkan berdasarkan masa kerja, dan untuk variabel Non Performing Loan menggunakan rasio NPL tahun 2010-2014 per triwulan. Dari hasil analisis korelasi pearson didapat korelasi antara SPI Pemberian Kredit dengan Non performing Loan adalah -0,844. Angka tersebut menunjukan adanya hubungan (korelasi) antara sistem pengendalian internal pemberian kredit dengan Non Performing Loan karena nilai $\mathrm{r}$ sebesar $-0,844$ lebih besar dari 0,5. Selanjutnya tingkat hubungan antara sistem pengendalian internal pemberian kredit dengan NPL pada $\mathrm{r}-0,844$ berada pada interval koefisien antara $0,800-1,000$ yang berarti tingkat hubungan antara dua variabel tersebut sangat kuat. Sedangkan arah hubungan adalah negatif karena nilai $r$ negatif, hal ini sejalan dengan teori yang mengemukakan bahwa sistem pengendalian internal pemberian kredit memiliki hubungan negatif dengan Non Performing Loan, yang berarti bahwa semakin baik sistem pengendalian internal pemberian kredit maka semakin rendah nilai kredit bermasalah.

3. Uji Signifikansi Koefisien Korelasi Parsial (Uji t)

Dari tabel diatas dapat diketahui bahwa nilai t hitung untuk variabel Sistem Pengendalian Internal Pemberian Kredit adalah -6,689 dengan nilai signifikansi (Sig.) sebesar 0,000. Artinya, nilai signifikansi lebih rendah dari taraf signifikansi sebesar 5\% atau 0,05. Dari hasil penghitungan didapat nilai $\mathrm{t}$ hitung sebesar $-6,689$ dengan taraf signifikan $0,05, \mathrm{n}=20, \mathrm{dk}$ (derajat kebebasan) adalah (20$2)=18$, maka didapat $t_{\text {tabel }}=2,101$. Sehingga dapat diketahui $t{ }_{\text {hitung }}>\mathrm{t}$ tabel $(-6,689<2,101>6,689)$. Dengan demikian, hal ini menunjukan hipotesis nol (Ho) ditolak dan hipotesis alternative (Ha) diterima, artinya bahwa sistem pengendalian internal pemberian kredit berperan dalam meminimalisasi Non Performing Loan.

4. Koefisien Determinasi

Analisis ini digunakan untuk mengetahui persentase pengaruh variabel independen terhadap variabel dependen. Koefisien ini menunjukkan seberapa besar persentase variabel independen 
mampu menjelaskan variabel dependen. Dari hasil analisis diatas diperoleh koefisien determinasi $\left(\mathrm{R}^{2}\right)=0,713$. Hal ini menunjukan bahwa sistem pengendalian internal pemberian kredit berperan secara signifikan dalam meminimalisasi non performing loan sebesar $71,3 \%$, sedangkan sisanya sebesar $(100 \%-71,3 \%=$ $28,7 \%$ ) dijelaskan atau dipengaruhi oleh faktor lain. Berdasarkan hasil penelitian ini, sistem pengendalian internal pemberian kredit memiliki hubungan negatif dan signifikan sebesar $71,3 \%$ terhadap non performing loan yang ditunjukan dengan nilai $r$ hitung $=-0,844$, signifikansi hitung $=0,000<0,05$, dan koefisien determinasi $\mathrm{R}^{2}$ $=0,713$. Hal ini berarti bahwa jika sistem pengendalian internal pemberian kredit naik maka non performing loan turun dan sebaliknya jika sistem pengendalian internal pemberian kredit turun maka non performing loan naik, dan kenaikan atau penurunan non performing loan yang dipengaruhi oleh sistem pengendalian internal pemberian kredit adalah sebesar $71,3 \%$ sedangkan sisanya sebesar $28,7 \%$ dipengaruhi oleh faktor lain. Hal ini sejalan dengan teori yang mengemukakan bahwa sistem pengendalian internal pemberian kredit memiliki hubungan negatif dengan Non Performing Loan, yang berarti bahwa semakin baik sistem pengendalian internal pemberian kredit maka semakin rendah nilai kredit bermasalah.

\section{Penutup}

\subsection{Simpulan}

Sistem pengendalian internal pemberian kredit sangat berperan dalam meminimalisasi non performing loan pada PT Bank Mitraniaga, Tbk, hal ini berdasarkan hasil penelitian dari perhitungan tingkat korelasi sebesar $84,4 \%$, dan koefisien determinasi sebesar $71,3 \%$ sedangkan sisanya dijelaskan atau dipengaruhi oleh faktor lain yang tidak diteliti seperti faktor eksternal, faktor internal nasabah, dan faktor kegagalan bisnis.

\subsection{Saran}

Bagi penelitian-penelitian selanjutnya, hasil penelitian ini dapat digunakan sebagai bahan perbandingan dan referensi untuk penelitian selanjutnya mengenai sistem pengendalian internal pemberian kredit dan non performing loan. Selain itu penelitian ini hanya terbatas pada beberapa sub unsur dari sistem pengendalian internal dan periode yang terbatas. Disarankan untuk dilakukan penelitian selanjutnya yang dapat mengurangi keterbatasan penelitian ini, yaitu sebaiknya penelitian selanjutnya memperbanyak sub unsur yang diteliti, dan menambahkan periode penelitian.

\section{Daftar Pustaka}

Annual Report Bank Mitraniaga 20102014 (diakses http://www.mitraniaga.com/ pada tanggal 03 Maret 2014)

Bank Indonesia. 2014. Peraturan nomor 6/10/PBI/2004 tanggal 12 April 2004 tentang Sistem Penilaian Tingkat Kesehatan Bank Umum. Bank Indonesia.

Eddy Mulyadi S., Ketut Sunarta, Jaenudin, Herdiyana, Sri Hartini, Yohanes Indrayono, Lesti Hartari, dan Ellyn Octavianty. 2014. Pedoman Seminar S1. Universitas pakuan, Bogor.

Eddy Mulyadi S., Ketut Sunarta, Jaenudin, Herdiyana, Sri Hartini, Yohanes Indrayono, Lesti Hartari, 
dan Ellyn Octavianty. 2014. Pedoman Penulisan Skripsi S1. Universitas Pakuan, Bogor.

Gelina, Ulric dan Richard dull. 2009. Accounting Information System. $8^{\text {th }}$ edition. Pearson education, Inc.

Hery. 2013. Akuntansi Dasar 1 dan 2. Jakarta : Gramedia Widiasarana Indonesia.

Hery. 2013. Akuntansi Keuangan Menengah. Jakarta : CAPS (Center Of Academic Publishing Service).

Ikatan Bankir Indonesia. 2014. Memahami Bisnis Bank. Jakarta : Gramedia Pustaka Utama.

Ikatan Bankir Indonesia dan Lembaga Sertifikasi Profesi Perbankan. 2014. Mengelola Bank Komersial. Jakarta : Gramedia Pustaka Utama.

Kasmir. 203. Dasar-dasar Perbankan. Jakarta : Raja Grafindo Persada.

Mulyadi. 2002. Auditing. Jakarta : Salemba 4.

Mahmoeddin. 2010. Melacak Kredit Bermasalah. Jakarta : Pustaka Sinar Harapan.
Martono, 2013. Bank dan Lembaga Keuangan Lain. Yogyakarta : Ekonisia.

Warren, Reeve dan Fess. 2006. Accounting Pengantar akuntansi. Buku kedua edisi 21. Jakarta : Salemba Empat.

Wawan H. Purwanto. 2011. Risiko Manajemen Perbankan. Jakarta : CMB Press, Jakarta.

Olla Auryna. 2009. Peran Pengendalian Internal Piutang dalam Meminimalkan Kerugian. Skripsi Program Sarjana Universitas Sumatera Utara.

Hery Sofyan. 2008. Manfaat Sistem Pengendalian Piutang dalam Meminimalisasi Piutang Tak Tertagih. Skripsi Program Sarjana Universitas Widyatama.

Dewa Putu Gede Sumerta Yasa. 2013. Pengaruh Komponen Pengendalian Internal Kredit pada Kredit Bermasalah. Skripsi program sarjana univeristas Udayana. 


\section{LAMPIRAN}

Lampiran 1.

Hasil Perhitungan Nilai Korelasi Sistem Pengendalian Internal Pemberian Kredit Results Correlation Value Calculation Internal Control Systems of Credit

\begin{tabular}{|c|c|c|c|}
\hline Pertanyaan & r hitung & r kritis & Keterangan \\
\hline 1 & 0.452 & 0.3 & Valid \\
\hline 2 & 0.332 & 0.3 & Valid \\
\hline 3 & 0.471 & 0.3 & Valid \\
\hline 4 & 0.471 & 0.3 & Valid \\
\hline 5 & 0.330 & 0.3 & Valid \\
\hline 6 & 0.486 & 0.3 & Valid \\
\hline 7 & 0.775 & 0.3 & Valid \\
\hline 8 & 0.857 & 0.3 & Valid \\
\hline 9 & 0.893 & 0.3 & Valid \\
\hline 10 & 0.805 & 0.3 & Valid \\
\hline 11 & 0.591 & 0.3 & Valid \\
\hline 12 & 0.472 & 0.3 & Valid \\
\hline 13 & 0.580 & 0.3 & Valid \\
\hline 14 & 0.580 & 0.3 & Valid \\
\hline 15 & 0.738 & 0.3 & Valid \\
\hline 16 & 0.795 & 0.3 & Valid \\
\hline 17 & 0.788 & 0.3 & Valid \\
\hline 18 & 0.744 & 0.3 & Valid \\
\hline 19 & 0.856 & 0.3 & Valid \\
\hline 20 & 0.856 & 0.3 & Valid \\
\hline 21 & 0.856 & 0.3 & Valid \\
\hline 22 & 0.820 & 0.3 & Valid \\
\hline 23 & 0.775 & 0.3 & Valid \\
\hline 24 & 0.784 & 0.3 & Valid \\
\hline 25 & 0.867 & 0.3 & Valid \\
\hline 26 & 0.747 & 0.3 & Valid \\
\hline 27 & 0.756 & 0.3 & Valid \\
\hline 28 & 0.861 & 0.3 & Valid \\
\hline 30 & 0.845 & 0.3 & Valid \\
\hline 0.615 & 0.3 & Valid \\
\hline
\end{tabular}

Sumber: Data diolah dengan SPSS V19

\section{Lampiran 2.}

Uji Reliabilitas Sistem Pengendalian Internal Pemberian Kredit

Test Reliability Internal Control System of Credit Reliability Statistics

\begin{tabular}{|r|r|}
\hline $\begin{array}{c}\text { Cronbach's } \\
\text { Alpha }\end{array}$ & N of Items \\
\hline .964 & 30 \\
\hline
\end{tabular}

Sumber: Data diolah dengan SPSS V19 
Lampiran 3.

Nilai Sistem Pengendalian Internal dan Non Performing Loan

Value Internal Control System and Non-Performing Loan

\begin{tabular}{|c|c|c|}
\hline No & $\begin{array}{c}\text { Total Score } \\
\text { (Variabel } \mathrm{x})\end{array}$ & $\begin{array}{c}\text { Rasio NPL } \\
\text { (Variabel Y) }\end{array}$ \\
\hline 1 & 121 & 0.0016 \\
\hline 2 & 124 & 0.0019 \\
\hline 3 & 119 & 0.0027 \\
\hline 4 & 120 & 0.0026 \\
\hline 5 & 113 & 0.0032 \\
\hline 6 & 103 & 0.0033 \\
\hline 7 & 112 & 0.0031 \\
\hline 8 & 126 & 0.0024 \\
\hline 9 & 132 & 0.0014 \\
\hline 10 & 143 & 0.0012 \\
\hline 11 & 134 & 0.0012 \\
\hline 12 & 129 & 0.0016 \\
\hline 13 & 123 & 0.0017 \\
\hline 14 & 114 & 0.0028 \\
\hline 15 & 124 & 0.0013 \\
\hline 16 & 124 & 0.0018 \\
\hline 17 & 127 & 0.0025 \\
\hline 18 & 91 & 0.0177 \\
\hline 19 & 91 & 0.0143 \\
\hline 20 & 98 & 0.0130 \\
\hline & & \\
\hline
\end{tabular}

Tabel 4.

Analisis Korelasi Peran SPI Pemberian Kredit dan Non Performing Loan SPI Role Correlation Analysis of Credit and Non-Performing Loan

Correlations

\begin{tabular}{|ll|r|r|}
\hline & \multicolumn{1}{|c|}{$\begin{array}{c}\text { SPI } \\
\text { Pemberian } \\
\text { Kredit }\end{array}$} & $\begin{array}{c}\text { Non } \\
\text { Performing } \\
\text { Loan }\end{array}$ \\
\hline SPI Pemberian & Pearson Correlation & 1 & $-.844^{* *}$ \\
Kredit & Sig. (2-tailed) & 20 & .000 \\
& $\mathrm{~N}$ & $-.844^{* *}$ & 20 \\
\hline Non Performing & Pearson Correlation & .000 & 1 \\
Loan & Sig. (2-tailed) & 20 & 20 \\
\hline
\end{tabular}

**. Correlation is significant at the 0.01 level (2-tailed)

Sumber: Data diolah dengan SPSS V 19 
Tabel 5.

Uji Signifikansi Koefisien Korelasi Parsial (Uji t)

Test t Partial Correlation Coefficient Significance

Coefficients $^{\text {a }}$

\begin{tabular}{|l|r|r|r|r|r|}
\hline \multirow{2}{*}{ Model } & \multicolumn{2}{|c|}{$\begin{array}{c}\text { Unstandardized } \\
\text { Coefficients }\end{array}$} & $\begin{array}{c}\text { Standardized } \\
\text { Coefficients }\end{array}$ & \multirow{2}{*}{$\mathrm{T}$} & \multirow{2}{*}{ Sig. } \\
\cline { 2 - 4 } & \multicolumn{1}{|c|}{$\mathrm{B}$} & \multicolumn{1}{c|}{ Std. Error } & Beta & & \\
\hline (Constant) & .039 & .005 & & 7.422 & .000 \\
SPI Pemberian Kredit & .000 & .000 & -.844 & -6.689 & .000 \\
\hline
\end{tabular}

a. Dependent Variable: Non Performing Loan

Sumber : Data diolah dengan SPSS v19

Tabel 6.

Koefisien Determinasi

Coefficient of Determination

\begin{tabular}{|l|c|r|r|r|}
\multicolumn{7}{c|}{ Model Summary $^{\text {b }}$} \\
Model & \multicolumn{1}{|c|}{ R } & R Square & $\begin{array}{c}\text { Adjusted R } \\
\text { Square }\end{array}$ & $\begin{array}{r}\text { Std. Error of } \\
\text { the Estimate }\end{array}$ \\
\hline 1 & $.844^{\mathrm{a}}$ & .713 & .697 & .0026552 \\
\hline
\end{tabular}

a. Predictors: (Constant), SPI Pemberian Kredit

b. Dependent Variable: Non Performing Loan

Sumber : Data diolah dengan SPSS V19 